\title{
ВПЛИВ ВІРУСНОГО НАВАНТАЖЕННЯ ВІРУСОМ ІМУНОДЕФІЦИТУ ЛЮДИНИ НА ВИЖИВАННЯ ХВОРИХ ІЗ ВІЛ-ІНФЕКЦІЄЮ ПРОТЯГОМ 5 РОКІВ СПОСТЕРЕЖЕННЯ
}

\author{
Д3 «Дніпропетровська медична академія МОЗ України», м. Дніпро, Україна
}

\begin{abstract}
Мета: на основі 5-річного спостереження ВІЛ-інфікованих хворих, яким було призначено ВААРТ, оцінити вплив вірусного навантаження ВIЛ PHK та $\mathrm{CD}^{+}$на початку високоактивної антиретровірусної терапії на смертність пацієнтів.

Матеріали і методи. Аналіз хворих проводили з урахуванням клінічних і лабораторних показників. Використовували описову статистику кількісних даних у групах; кореляційний аналіз.

Результати. Всі хворі отримували високоактивну антиретровірусну терапію не менше 5 років. Імунофренотипування периферійної крові показало такі результати: медіана (Ме, 25-75 процентиль) рівня CD4+ склала 186 (90-262) копій/мл, вірусне навантаження - 75,358 (19,091-326,273) ВІЛ РНК копій/мл. За 5 років спостереження померли 63 пацієнти. Найбільший відсоток хворих на ВІЛ-інфекцію померли у перші 12 місяців лікування і склали 58,73 \%. Протягом наступних двох років проведення лікування щорічно померли 11,11 та 14,28 \% відповідно. На четвертому році після початку ВААРТ померли 11,11 \% хворих. За 5 рік проведення ВААРТ померли 4,76 \% хворих.

Висновки. У ВІЛ-інфрікованих хворих, яким було призначено ВААРТ, визначено зв'язок між кількістю Т-лімфоцитівхелперів та вірусним навантаженням ( $r s=-0,821 ; p=0,000)$ у період 5-річного спостереження. Найбільший накопичений ризик смерті - 0,1, виявлено у групах пацієнтів із більшим ступенем імуносупресії.
\end{abstract}

КЛЮЧОВІ СЛОВА: ВІЛ-інфекція; ВААРТ; CD4+ Т-лімфоцити; вірусне навантаження.

Відповідно до даних Глобальної статистики 2017 р. ЮНЕЙДС та ВООЗ з початку епідемії в світі інфрікувались вірусом імунодесріциту людини (ВІЛ) 76,1 млн людей, близько 35 млн - померли від захворювань, пов'язаних із ВІЛ, та ще близько 37 млн людей станом на початок 2018 р. живуть 3 ВІЛ. Складною залишається епідемічна ситуація з ВІЛ-інфекцією в Україні, де, за оціночними даними, на початок 2018 р. проживало 241 тис. людей 3 ВІЛ усіх вікових категорій. Рівень поширеності ВІЛ у віковій групі 15-49 років становив 0,98 \%. За оперативними даними ДУ «Центр громадського здоров'я МОЗ України» за період 1987- 2017 рр. у країні офріційно зареєстровано 315618 випадків ВІЛ-інсрекції серед громадян України, у тому числі 102205 випадків захворювання на СНІД та 45074 випадки смерті від захворювань, зумовлених СНІДом. Станом на 01.01.2018 р. під медичним наглядом перебувало 141371 ВІЛ-інфрікована особа, серед яких кожен третій - 3 діагнозом СНІД. Означена ситуація потребує всебічного вивчення проблемних питань ВІЛ-інфекції, включно пошуки можливостей прогнозування її перебігу та ефрективності лікування.

У свою чергу, раціональне планування ВААРТ полягає в тому, щоб швидко і якомога на довгий час досягти вірусологічної, імунологічної, клінічної та протиепідемічної мети $[1,3,5,6]$. Відомо, що вірусоспецисрічна Т-клітинна імунна відповідь відіграє ключову роль у розвитку інфрекції, викликаної вірусом імунодесріциту людини. При розвитку ВІЛ-інфекції поряд зі зниженням кількості Т-лімсроцитів-хелперів порушується активація, проліферація і диференціювання клітин. Рівень вірусного навантаження (BH) у крові визначає прогресування захворювання і розвиток опортуністичних інфекцій, дозволяє передбачити швидкість зниження кількості лімсроцитів. Передача ВІЛ при будь-якому виді контакту залежить від ВН $[4,5]$.

Дослідження ВІЛ-інфікованих показали, що для успішного пригнічення репродукції ВІЛ дотримання медичних приписів (тривалості курсу, доз препаратів, їх комбінації, часу приймання) повинно бути виконаним не менш ніж на $95 \%$. При недотриманні правил лікування початкова ефективність ВААРТ знижується, вірус знову активується, і посилюється здатність збудника до численних мутацій, через що розвивається стійкість до одного АРВ-препарату, а надалі нерідко перехресна стійкість до інших препаратів [7].

Перший важливий період оцінки ефективності ВАAРТ, зокрема вірусологічної, визначено терміном 6 місяців після початку лікування. Відповідно до клінічного протоколу [4], при продовженні визначення РНК ВІЛ у хворого через 24 тижні лікування (вірусне навантаження вище 50 копій/ мл), необхідно встановити можливі причини невдачі лікування для вибору тактики подальшого 
ведення пацієнта. У разі встановленої вірусологічної невдачі лікування постає ключове питання: наскільки небезпечним є продовження цієї схеми ВААРТ і чи необхідна заміна схеми. Вірусологічна неефективність може бути пов'язана як з лікарською стійкістю ВІЛ, так і з відсутністю прихильності та з іншими факторами. Тобто саме в цей час дуже важливо оцінити прихильність для вибору подальшої тактики ведення хворого $[2,8]$.

Мета дослідження: на основі 5-річного спостереження ВІЛ-інфікованих хворих, яким було призначено ВААРТ, оцінити вплив вірусного навантаження ВІЛ РНК та CD4+ на початку ВААРТ на смертність пацієнтів.

Матеріали і методи. Під нашим наглядом перебувало 450 хворих, яким було призначено АРТ у 2010 р. Спостереження проводили протягом 5 років у Дніпропетровському обласному центрі з профрілактики та боротьби зі СНІДом. Результати моніторингових візитів було взято 3 амбулаторних карток хворих. Аналіз хворих проводили з урахуванням соціально-демограсрічних, клінічних і лабораторних показників. Поряд із рутинними методами лабораторного обстеження (загальний аналіз крові, біохімічне дослідженні крові та ін.) використовували методи імуноферментного аналізу для діагностики опортуністичних інфекцій, оцінку CD4+ Т-лімфроцитів методом проточної цитофлюорометрії, контроль вірусного навантаження РНК ВІЛ-методом полімеразної ланцюгової реакції.

Використовували такі математико-статистичні методи: описова статистика кількісних даних у групах; нормальність розподілу кількісних ознак у вибірці за допомогою критерію Шапіро-Уілка; кореляційний аналіз (коефріцієнт кореляції - R) двох ознак непараметричним методом Спірмена для оцінки напрямку, сили, статистичної значущості кореляційного зв'язку між ознаками. Для оцінки виживання хворих на ВІЛ-інфекцію, які отримували ВААРТ, використовували метод КапланаМейєра. При аналізі враховували смерть пацієнта від будь-яких причин за період спостереження (загальна летальність).

Результати дослідження та їх обговорення. 450 хворих на ВІЛ-інфекцію, які отримували ВААРТ не менше ніж 5 років та перебували під наглядом у Дніпропетровському обласному центрі СНІДу, поділено на 4 групи за кількістю первинних $\mathrm{CD}^{+}$Т-лімфоцитів із ранговим кроком 100 клітин/мл: до 1 групи увійшли 123 пацієнти із кількістю CD4 ${ }^{+}$Т-лімфроцитів - від 0 до 100 клітин/мл, до 2 групи - 114 пацієнтів із кількістю CD4+ Т-лімфроцитів від 101 до 200 клітин/мл, до 3 та 4 груп - 142 та 71 пацієнт 3 показниками CD4 ${ }^{+}$ Т-лімфоцитів, відповідно, 201-300 клітин/мл та 301 і більше клітин/мл. Загальну характеристику груп наведено у таблиці 1.

Таблиця 1. Характеристика груп хворих на ВІЛ, які отримують ВААРТ

\begin{tabular}{|c|c|c|c|c|}
\hline Назва & $\begin{array}{l}\text { Група 1 } \\
(\mathrm{n}=123)\end{array}$ & $\begin{array}{l}\text { Група } 2 \\
(\mathrm{n}=114)\end{array}$ & $\begin{array}{l}\text { Група } 3 \\
(\mathrm{n}=142)\end{array}$ & $\begin{array}{c}\text { Група } 4 \\
(\mathrm{n}=71)\end{array}$ \\
\hline $\begin{array}{l}\text { Вік, роки } \\
(\mathrm{Me}, 25-75 \%)\end{array}$ & $35(31-43)$ & $35(29-43)$ & $34(28-39)$ & $30(26-35)$ \\
\hline $\begin{array}{l}\text { Стать (n) } \\
\text { чол. (\%) } \\
\text { жін. (\%) }\end{array}$ & $\begin{array}{l}71(57,72 \%) \\
52(42,28 \%)\end{array}$ & $\begin{array}{c}48(42,11 \%) \\
66(57,89 \%)\end{array}$ & $\begin{array}{l}47(33,10 \%) \\
95(66,90 \%)\end{array}$ & $\begin{array}{l}28(39,44 \%) \\
43(60,56 \%)\end{array}$ \\
\hline $\begin{array}{l}\text { Парентеральний шлях } \\
\text { передачі ВІЛ (n), \% }\end{array}$ & $59(47,97 \%)$ & $59(51,75 \%)$ & $57(40,14 \%)$ & $32(45,07 \%)$ \\
\hline $\begin{array}{l}\text { Статевий шлях передачі } \\
\text { ВІЛ (n), \% }\end{array}$ & $64(52,03 \%)$ & $55(48,25 \%)$ & $85(59,86 \%)$ & $39(54,93 \%)$ \\
\hline $\begin{array}{l}\mathrm{CD}^{+} \text {Т-лімфоцити } \\
(\mathrm{Me}, 25-75 \%), \text { клітин/мл }\end{array}$ & $41(19-72)$ & $152(124-171)$ & 245 (223-265) & $344(321-360)$ \\
\hline $\begin{array}{l}\text { Вірусне навантаження } \\
\text { (Ме, 25-75 \%), ВІЛ РНК, } \\
\text { копій/мл }\end{array}$ & $\begin{array}{c}236,824 \\
(56,110-626,570)\end{array}$ & $\begin{array}{c}97,421 \\
(23,069-372,308)\end{array}$ & $\begin{array}{c}45,074 \\
(10,898-165,440)\end{array}$ & $\begin{array}{c}28,987 \\
(10,401-107,520)\end{array}$ \\
\hline HVC (n), \% & $39(31,71 \%)$ & $45(39,47 \%)$ & $39(27,46 \%)$ & $20(28,17 \%)$ \\
\hline $\begin{array}{l}\text { Орофрарінгеальний } \\
\text { кандидоз (n), \% }\end{array}$ & $67(54,47 \%)$ & $67(54,47 \%)$ & $55(38,73 \%)$ & $29(40,85 \%)$ \\
\hline Токсоплазмоз (n), \% & $44(35,77 \%)$ & $38(33,33 \%)$ & $44(30,99 \%)$ & $16(22,54 \%)$ \\
\hline Летальність (n), \% & $29(23,58 \%)$ & $21(18,42 \%)$ & $10(7,04 \%)$ & $3(4,23 \%)$ \\
\hline
\end{tabular}

Середній вік хворих склав 34 (29-41) роки. Всі пацієнти отримували АРТ не менше ніж 5 років. Імунофенотипування периферійної крові показало такі результати: медіана (25-75 процентиль) кількості Т-лімфоцитів-хелперів (CD4+) для
1 групи склала 41 (19-72) клітин/мл, для 2 групи - 152 (124-171) клітин/мл, для 3 і 4 груп, відповідно, 245 (223-265) і 344 (321-360) клітин/мл. Одночасно, вірусне навантаження (медіана, 25-75 процентиль) для 1 групи склало 
$236,824(56,110-626,570)$ ВІЛ РНК копій/мл, для 2 - 97,421 (23,069-372,308) копій/мл, для 3 групи - 45,074 (10,898-165,440) та 28,987 $(10,401-107,520)$ копій/мл для 4 групи пацієнтів.

За результатами кореляційного аналізу між основними характеристиками імунної системи та вірусним навантаженням встановлено такі закономірності: для всіх чотирьох груп визначено статистично значущий зв'язок кількості Т-лімфоцитів-хелперів із вірусним навантаженням: для 1 групи (rs=-0,821; $\mathrm{p}=0,000)$, для 2 групи (rs=-0,866; $p=0,000)$, для 3 групи $\left(r_{s}=-0,801\right.$; $p=0,000)$ та для 4 групи $\left(r_{s}=-0,754 ; p=0,000\right)$.

Зв'язок між зменшенням кількості $\mathrm{CD}^{+}$ Т-лімороцитів та показником ВН може бути пов'язаний з безпосередньою загибеллю клітин у результаті дії вірусу, з розвитком ВІЛ-індукованого апоптозу [4]. Високе вірусне навантаження погіршує імунологічний стан ВІЛ-інфрікованих. Виявлені зміни показників клітинного імунітету призводять до прогресії захворювання і збільшують ризик передачі вірусу.

При аналізі виживання за методом КапланаМейєра, у хворих на ВІЛ-інфекцію, які отримували ВААРТ, враховували смерть пацієнта від будь-яких причин за період спостереження (загальна летальність).

Ретроспективний аналіз виживання 450 паці$\epsilon$ нтів із ВІЛ-інфекцією Дніпропетровського обласного центру профрілактики і боротьби зі СНІДом, які отримували ВААРТ протягом 5 років, починаючи 32010 р., показав загальний кумулятивний ризик летальності 14 \%. За 5 років спостереження померли 63 пацієнти. Якщо враховувати щорічну летальність, найбільша кількість померлих хворих спостерігалась у перші 12 місяців лікування і склала 58,73 \%. Більшість цих пацієнтів померла внаслідок розвитку синдрому відновлення імунної системи і активації опортуністичних інфекцій. Протягом наступних двох років (2-3 років) проведення лікування, щорічний відсоток померлих склав 11,11 та 14,28 \% відповідно. На четвертому році після початку ВААРТ померли 11,11 \% хворих та за 5 рік від початку терапії померли 4,76 \% хворих.

На рисунках 1-4 наведено кумулятивний ризик летальності у чотирьох групах спостереження залежно від рівня вірусного навантаження при якому було призначено ВААРТ.

На рисунку 1 можна побачити, що хворі з рівнем $\mathrm{CD4}^{+}$лімфоцитів до 100 клітин мають найбільший рівень ризику смерті хворих, який складає 0,1 у перший рік призначення ВААРТ.

На рисунку 2 видно, що у хворих з рівнем CD4 ${ }^{+}$ лімороцитів 152 (124-171) накопичений ризик смерті складає 0,1 вже на початку 2 року приймання ВААРТ незалежно від кількості ВІЛ РНК у крові.

У 3 групі (рис. 3) спостерігають зв'язок ризику смерті з показником вірусного навантаження. Так у хворих, які мають ВН більше 100,000 РНК копій/мл, накопичений ризик смерті у перший рік приймання ВААРТ складає 0,04, у той час, як у хворих із рівнем ВІЛ РНК у крові менше 100,000 копій/мл накопичений ризик смерті на першому році лікування склав 0,00.

Для хворих із рівнем CD4+ лімфоцитів більше 300 клітин та які мають рівень вірусного навантаження більше 100,000 РНК копій/мл (рис. 4) накопичений ризик становить 0,06 та тримається весь час, що дозволяє припустити, що летальність у цієї групи хворих залежить від інших, частіше зовнішніх фракторів.

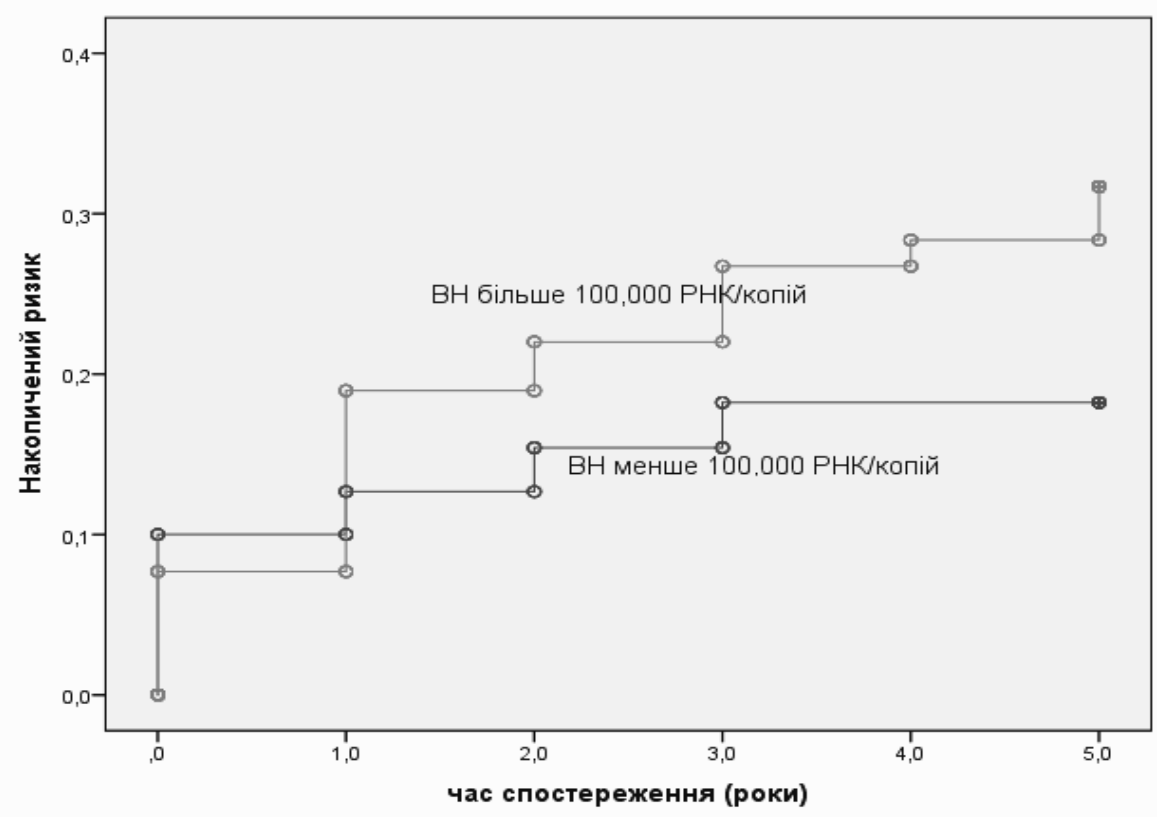

Puc. 1. Накопичений ризик летальності у 1 групі спостереження. 


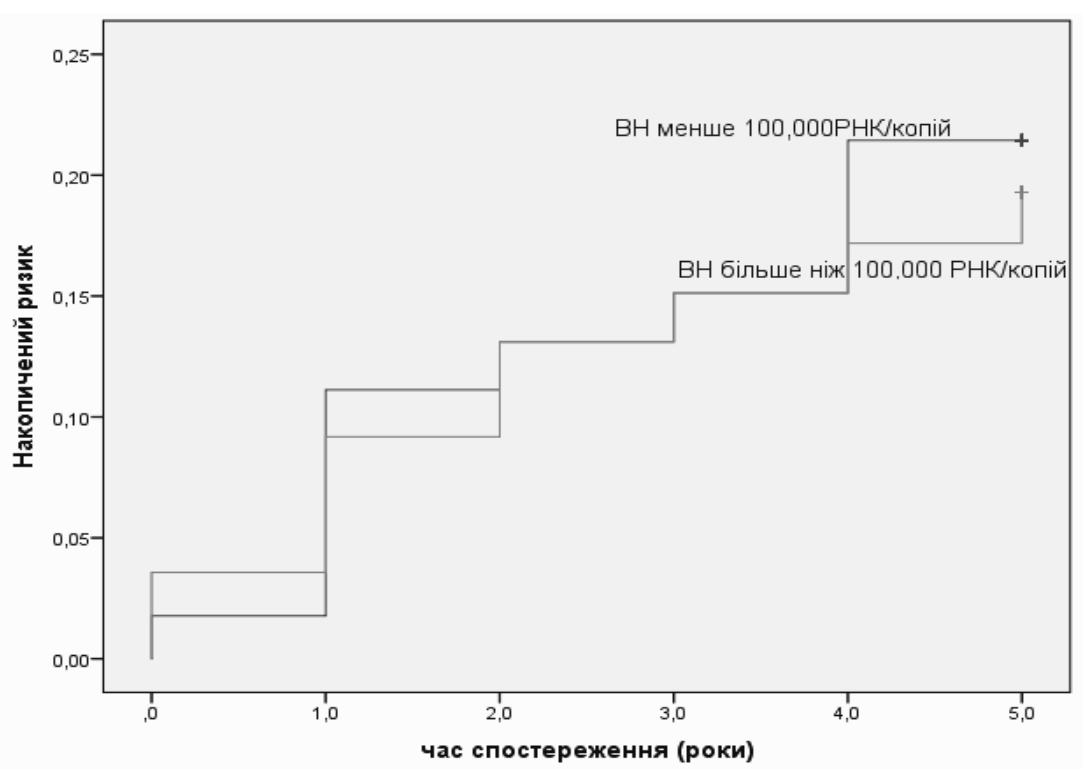

Puc. 2. Накопичений ризик летальності у 2 групі спостереження.

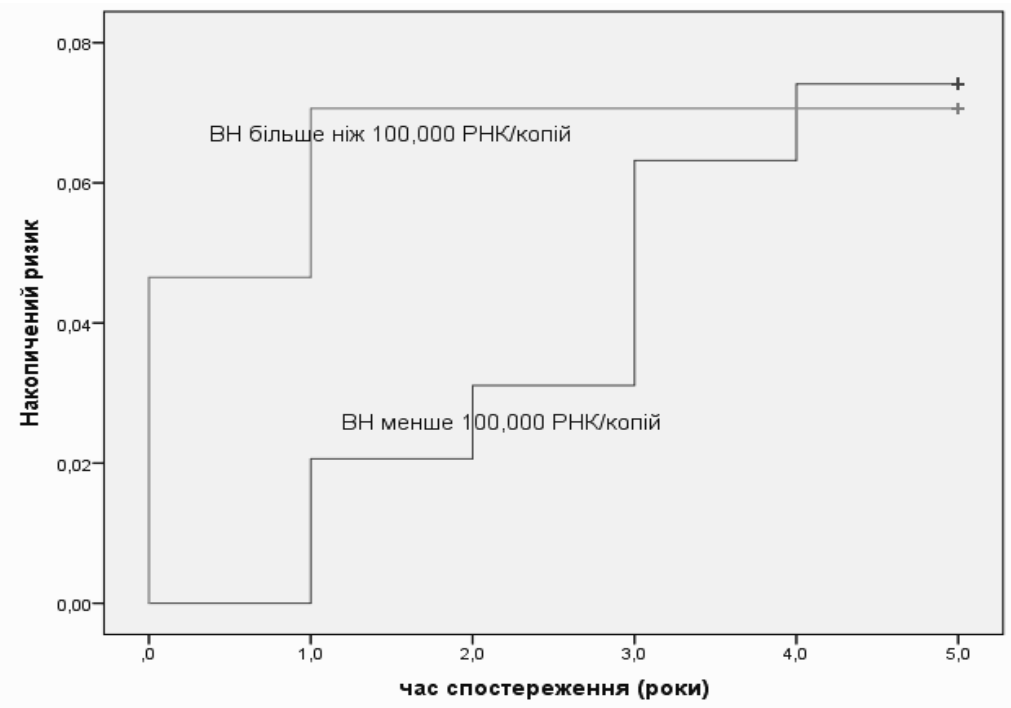

Puc. 3. Накопичений ризик летальності у 3 групі спостереження.

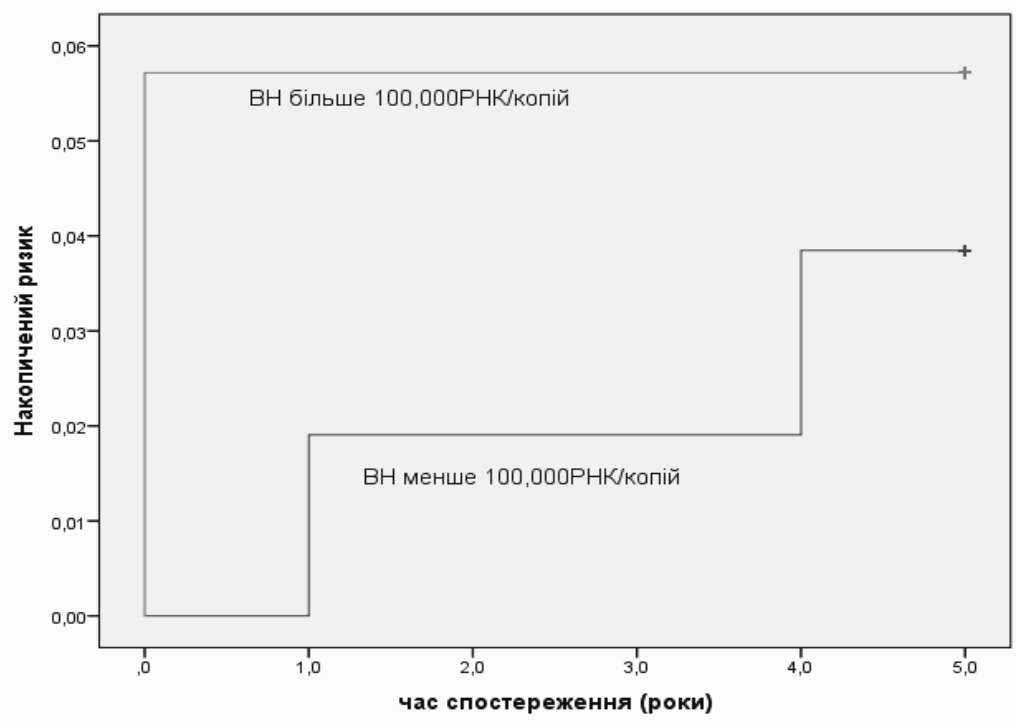

Puc. 4. Накопичений ризик летальності у 4 групі спостереження. 
Таким чином, проведений аналіз дозволив визначити взаємозв'язок між рівнем CD4+ лімфоцитів та кількістю вірусного навантаження при призначенні антиретровірусної терапії.

\section{Висновки}

1. У ВІЛ-інфікованих хворих, яким було призначено ВААРТ у період 5-річного спостереження, визначено зв'язок між кількістю Т-лімфоцитів-хелперів та вірусним навантаженням ( $r s=-0,821 ; p=0,000)$.

2. Найбільший накопичений ризик смерті - 0,1, виявлено у групах хворих із більшим ступенем імуносупресії - кількістю $\mathrm{CD}^{+} 200$ клітин/мл та менше (1 та 2 групи), у той час, як у пацієнтів, які мали кількість CD4+ більше 200 клітин/мл (34 групи) аналогічний показник був меншим за той же період та склав 0,02.

3. У хворих, в яких на момент призначення терапії вірусне навантаження ВІЛ РНК склало менше 100,000 копій/мл, а рівень CD4 ${ }^{+}$лімфроцитів становив більше 300 клітин/мл, накопичений ризик летальності не мав впливу з боку цих фракторів, що потребує подальшого вивчення цього питання.

\section{Список літератури}

1. Клінічний протокол антиретровірусної терапії ВІЛ-інфекції у дорослих та підлітків / затверджений наказом МО3 України від 12.07.2010 р. № 551. - К. : МОЗ України, 2010. - 164 с.

2. Покровская А. В. Факторы, влияющие на течение ВИЧ-инфекции / А. В. Покровская // Эпидемиология и инсрекционные болезни. - 2010. - № 3. - С. 60-63.

3. A systematic review of the impact of alcohol use disorders on HIV treatment outcomes, adherence to antiretroviral therapy and health care utilization / M. M. Azar, S. A. Springer, J. P. Meyer, F. L. Altice // Drug Alcohol. Depend. - 2010. Vol. 112, No. 3. - P. 178-193.

4. Atkinson M. J. An evidence-based review of treatment-related determinants of patients' nonadherence to HIV medications / M. J. Atkinson, J. J. Petrozzino // II AIDS Patient Care STDS. - 2009. - Vol. 23, No. 11. - P. 903-914.

5. Boulware D. R. Clinical features and serum biomarkers in HIV immune reconstitution inflammatory synd bryptococcal meningitis: a prospective cohort study / D. R. Boulware, D. B. Meya, T. L. Bergemann // PLoS Med. - 2010. - Vol. 7 , No. 12. - P. 380-384.

6. Correlates and predictors of adherence to highly active antiretroviral therapy: overview of published literature / A. Ammassari, M. P. Trotta, R. Murri [et al.] // J. Acquir. Immune. Defic. Syndr. - 2002. - Vol. 31, No. 3. - P. $123-127$.

7. Trinchieri G. Interleukin-10 production by effector T cells: Thl cells show self control / G. Trinchieri // J. Exp. Med. - 2007. Vol. 204, No. 2. - P. 239-243.

8. Wojcicki J. M. Socioeconomic status as a risk factor for HIV infection in women in East, Central and Southern Africa: a systematic review / J. M. Wojcicki // J. Biosoc. Sci. - 2005. - Vol. 37, No. 1. - P. 1-36.

\section{References}

1. Nakaz MOZ Ukrainy № 551 vid 12.07.2010 r. "Pro zatverdzhennia klinichnoho protokolu antiretrovirusnoi terapii VILinfektsii u doroslykh ta pidlitkiv" [Order of the Ministry of Health of Ukraine dated July No 551 of 12.07.2010. "About the solidification of the clinical protocol of antiretroviral therapy VIL-infectious diseases in the elderly and adolescents"]. [in Ukrainian].

2. Pokrovskaya A.V.(2010). Faktory, vliyayushchie na techenie VICH-infektsii [Factors influencing the course of HIV infection]. Epidemiologiya i infektsionnye bolezni - Epidemiology and Infectious Diseases, 3, 60-63 [in Russian].

3. Azar, M. M., Springer, S. A., Meyer, J. P., \& Altice F. L. (2010). A systematic review of the impact of alcohol use disorders on HIV treatment outcomes, adherence to antiretroviral therapy and health care utilization. Drug Alcohol. Depend., 112 (3), 178-193.

4. Atkinson, M. J. \& Petrozzino J. J. (2009). An evidence-based review of treatment-related determinants of patients' nonadherence to HIV medications. II AIDS Patient Care STDS, 23 (11), 903-914.

5. Boulware, D. R., Meya, D. B. \& Bergemann, T. L. (2010). Clinical features and serum biomarkers in HIV immune reconstitution inflammatory synd bryptococcal meningitis: a prospective cohort study. PLoS Med. 7, (12), 380-384.

6. Ammassari, A., Trotta, M. P., Murri, R. \& et al. (2002). Correlates and predictors of adherence to highly active antiretroviral therapy: overview of published literature. J. Acquir. Immune. Defic. Syndr., 31 (3), 123-127.

7. Trinchieri G. (2007). Interleukin-10 production by effector T cells: Thl cells show self- control. J. Exp. Med. 204 (2), $239-243$. 8. Wojcicki J. M. (2005). Socioeconomic status as a risk factor for HIV infection in women in East, Central and Southern Africa: a systematic review. J. Biosoc. Sci. 37 (1), 1-36.

\section{ВЛИЯНИЕ ВИРУСНОЙ НАГРУЗКИ ВИРУСОМ ИММУНОДЕФИЦИТА ЧЕЛОВЕКА НА ВЫЖИВАЕМОСТЬ БОЛЬНЫХ С ВИЧ-ИНФЕКЦИЕЙ В ТЕЧЕНИЕ 5 ЛЕТ НАБЛЮДЕНИЯ}

Е.В. Шевелева, Л.Р. Шостакович-Корецкая, Е.Ю. Литвин

ГУ «Днепропетровская медицинская академия МЗ Украины», г. Днепр, Украина

Цель: на основании 5-летнего наблюдения ВИЧ-инфицированных больных, которым была назначена BAАРТ, оценить влияние вирусной нагрузки РНК ВИЧ и $\mathrm{CD}^{+}$на смертность пациентов.

Материалы и методы. Анализ больных проводили с учетом клинических и лабораторных показателей. Использовали методы описательной статистики количественных данных в группах; корреляционный анализ. 
Результаты. Все больные получали высокоактивную антиретровирусную терапию (ВААРТ) не менее 5 лет. Иммунофенотипирования периферической крови показало следующие результаты: медиана (Ме, 25-75 процентиль) уровня CD4+ составила 186 (90-262) копий/мл, вирусная нагрузка - 75,358 (19,091$326,273)$ РНК ВИЧ копий/мл. За 5 лет наблюдения умерли 63 пациента. Если учитывать ежегодную летальность, большой процент больных ВИЧ-инфекцией умерли в первые 12 месяцев лечения и составили 58,73 \%. В течение следующих двух лет проведение лечения ежегодно умерли 11,11 и 14,28 \% соответственно. На четвертом году после начала ВААРТ умерли 11,11 \% больных. За 5 год проведения ВААРТ умерли 4,76 \% больных.

Выводы. У ВИЧ-инфицированных больных, которым была назначена ВААРТ, определенная связь между количеством Т-лимфоцитов-хелперов и вирусной нагрузкой ( $r s=-0,821 ; p=0,000)$ в период 5-летнего наблюдения. Наибольший накопленный риск смерти - 0,1, выявлен в группах пациентов с большей степенью иммуносупрессии.

КЛЮЧЕВЫЕ СЛОВА: ВИЧ-инфекция; ВААРТ; CD4+ Т-лимфоциты; вирусная нагрузка.

\section{THE IMPACT OF HIV VIRAL LOAD ON THE SURVIVAL OF PATIENTS WITH HIV INFECTION DURING A 5-YEAR FOLLOW-UP}

O.V. Shevelova, K.Yu. Lytvyn, L.R. Shostakovych-Koretskaya

Dnipropetrovsk Medical Academy of Health Ministry of Ukraine, Dnipro, Ukraine

Purpose: based on a 5-year follow-up of a cohort of HIV-infected patients who were assigned highly active antiretroviral therapy, to assess the impact of viral load of HIV and CD4 RNA on the beginning of highly active antiretroviral therapy on mortality.

Materials and Methods. The analysis of patients was carried out taking into account clinical and laboratory parameters. Mathematical and statistical methods were used: descriptive statistics of quantitative data in groups; correlation analysis (correlation coefficient $-r s$ ).

Results. All patients received highly active antiretroviral therapy (HAART) for at least 5 years. Immunophenotyping of peripheral blood showed the following results: median (IU, 25-75 percentile) CD4 + level was 186 (90-262) copies / ml, viral load-75.358 (19.091-326.273) RNA HIV copies/ml. Over five years of followup, 63 patients died. If we take into account the annual mortality, a large percentage of HIV patients died in the first 12 months of treatment and amounted to 58.73\%. Over the next two years, $11.11 \%$ and $14.28 \%$ died annually, respectively. In the fourth year after the start of highly active antiretroviral therapy, $11.11 \%$ of patients died. For the 5 th year of the HAART died $4.76 \%$ of patients.

Conclusions. In HIV-infected patients, who were assigned HAART to, there is a certain relationship between the number of T-lymphocytes-helpers and viral load ( $r=-0.821 ; p=0.000)$ during the 5 -year follow-up. The highest accumulated risk of death -0.1 , was found in groups of patients with a greater degree of immunosuppression.

KEY WORDS: HIV; HAART; CD4+ T-lymphocytes; viral load.

Рукопис надійшов до редакції 22.06.2018 p.

\footnotetext{
Відомості про авторів:

Шевельова Олена Володимирівна - асистент кафедри інфекційних хвороб ДЗ «ДМА МОЗ України»; тел.: +38(056) 726-44-71.

Шостакович-Корецька Людмила Романівна - доктор медичних наук, професор, завідувач кафредри інфекційних хвороб ДЗ «ДМА МОЗ України»; тел.: +38(056) 726-44-71.

Литвин Катерина Юріївна - кандидат медичних наук, доцент, доцент кафедри інсекційних хвороб ДЗ «ДМА МОЗ України»; тел.: +38(056) 726-44-71.
} 